general practitioners at large. The depressing fact remains that nothing remotely like all general practitioners counsel their smoking patients, let alone even realise that many of them smoke. In Australia, for example, where less than $10 \%$ of doctors smoke, general practitioners knowingly under the gaze of a research project examining their preventive interactions with patients could successfully identify only $56 \%$ of their smoking patients. ${ }^{9}$ In countries where much higher proportions of doctors and medical students smoke ${ }^{11}$ sometimes even higher proportions than in the adult population-the picture must surely be bleaker.

General practitioners have more than enough cessation packages and minimal intervention protocols available to them. By comparison, there have been few efforts to analyse why many doctors do not even raise the subject with their patients and why initial enthusiasm to attend training courses in cessation tends to wane when implementation is examined away from clinical trial settings. ${ }^{12} 13$

Few doctors would continue to prescribe a drug that "failed" $95 \%$ of the time-one, unkind, interpretation of the usual long term outcome of cessation protocols with minimal intervention. Doctors' training and their day to day expectations of achievement with drug treatments probably mean that many of them carry analogous expectations into their counselling of patients about smoking and the prescription of nicotine substitutes. There is no realistic hope that such expectations will ever be fulfilled, so for many doctors the result is probably despondency and diminished efforts with such patients.

Efforts should certainly continue to encourage doctors to make the most of the powerful opportunity offered by a clinical setting to encourage their patients to stop smoking. More needs to be done to show doctors that, although their success rate with individual patients may seem small, it is important in public health terms. But, plainly, for as long as the choice to smoke is made easy by the cultural, political, and economic environment so the clinical role of doctors in encouraging cessation will often seem futile.

Doctors have been in the forefront of public health lobbying for regulatory and fiscal "fences at the top of the cliff" that reduce the number of people falling into the rivers of long term tobacco use. Yet there may be a counterpart in smoking cessation to Julian Tudor Hart's “inverse care law."14 A testing of the inverse smoking research law would doubtless reveal that the more capable the intervention or policy of reducing the prevalence of smoking - for example, price rises, ${ }^{15}$ bans on smoking in the workplace, ${ }^{16}$ and advertising restrictions ${ }^{17}$ - the scarcer the research that describes its implementation.

Conversely, research about the minutiae of "downstream" approaches to smoking control oriented to the individual person continue to proliferate, with the generally unexceptional outcomes that Sanders has summarised. I look forward to the day when the Health Education Authority commissions a monograph that points to more effective ways in which doctors and others can undermine the British government's continuing defence of tobacco advertising.

SIMON CHAPMAN

University of Sydney,

Senior lecturer in community medicine

Westmead Hospital,

Westmead 2145,

Australia

1 Russell $M$, Wilson $C$, Taylor $C$, Baker $C$. Effect of general practitioners' advice against smoking. BMF 1979;ii:31-5.

2 Sanders D. Smoking cessation interventions: is patient education effective? London: Health Promotion Services Unit, London School of Hygiene and Tropical Medicine, 1992.

3 Ockene JK. Physician-delivered interventions for smoking cessation: strategies for increasing effectiveness. Prev Med 1987;16:723-37.

4 Schwartz J. Review and evaluation of smoking cessation methods: the US and Canada 1978-1985. Bethesda: National Institutes of Health, 1987

5 Lam W, Szc PC, Sacks HS, Chalmers TC. Meta-analysis of randomised controlled trials of nicotine chewing-gum. Lancet 1987;ii:27-30.

6 Kottke TE, Battista RN, Deffiesc GH, Brekke ML. Attributes of successful smoking cessation interventions in medical practice. A meta-analysis of 39 controlled trials. $尹 A M A$ 1988;259: 2883-9.

7 Glynn TJ, Boyd GM, Gruman JC. Essential elements of self-help/minimal intervention strategies for smoking cessation. Health Education Quarterly 1990;17:329-45.

8 Mattick RP, Baillie A, eds. An outline for approaches to smoking cessation: quality assurance project. Canberra: Australian Government Publishing Service, 1992. (National Campaign Against Drug Canberra: Australian Gover

9 Dickinson J, Wiggers J, Leeder S, Sanson-Fisher R. General practitioners' detection of patients' smoking status. Med $\mathcal{F}$ Aust 1989;150:420-6.

10 Tessier JF, Fréour P, Belougne D, Crofton J. Smoking habits, and attitudes of medical students towards smoking and anti-smoking campaigns in fourteen European countries. Eur Epidemiol 1989;5:311-9

11 Tessier JF, Fréour P, Nejiari C, Belougne D, Crofton JW. Smoking behaviour and attitudes towards smoking of medical students in Australia, Japan, USA, Russia, and Estonia. Tobacco Control 1993;2:24-9.

12 Copeman RC, Swannell PJ, Pincus DF, Woodhead KA. Utilization of the "smokescreen" smoking-cessation programme by general practitioners and their patients. Med $\mathcal{f}$ Aust
1989;151:83-7.

13 Borland R, Hill D. Are doctors doing enough to stop their patients smoking? Med $f$ Aust 1989;150:413-4.

14 Hart JT. The inverse care law. Lancet 1971;1:405-12.

15 Wasserman J. How effective are excise tax increases in reducing cigarette smoking? Am f Public Health 1992:82:19-20.

16 Woodruff TJ, Rosbrook B, Pierce J, Glantz SA. Lower levels of cigarette consumption found in Woodruff TJ, Rosbrook B, Pierce J, Glantz SA. Lower levels of cigaret
smoke-free workplaces in California. Arch Intern Med 1993;153:1485-93.

17 Laugesen $M$, Meads C. Tobacco advertising restrictions, price, consumption in OECD countries, 1960-1986. Br f Addict 1991;86:1343-54.

\title{
Steroid osteoporosis
}

\section{A pragmatic approach is needed while prospective trials are awaited}

The adverse effects of corticosteroids on bone have been known for over 50 years. We are now able to document these changes with reasonable accuracy by using bone densitometry, but we still do not know the mechanisms or the safe dose of steroids in a given period. Nor it is known whether steroid osteoporosis is preventable.

Studies of patients receiving long term steroid treatment for chronic diseases such as asthma, rheumatoid arthritis, or inflammatory bowel disease have shown that bone loss seems to be rapid initially with rates approaching 4-10\% a year, ${ }^{23}$ but, while bone loss is greatest in the first year, it probably continues for as long as treatment is being given. This loss of bone is important, but clinically osteoporotic fractures are the relevant end point, and there are few data on the association of steroids with fractures. Increased rates of vertebral fractures have been reported in many studies of patients with chronic diseases, but some of that increase may be attributable to the underlying disease. ${ }^{47}$ Steroids affect cortical sites (such as the neck of femur) as much as trabecular bone in the vertebra, ${ }^{3}$ but whether there is an increased risk of hip fracture in addition to the commonly associated vertebral and rib fractures is unknown. Some studies suggest that patients taking steroids suffer vertebral fractures at higher thresholds of spinal bone density than non-users, ${ }^{8}$ but by no means all patients taking steroids develop fractures. The wide variation may reflect genetic differences in susceptibility to corticosteroids or variability in the pharmacokinetics of steroids among individual people. Furthermore, some steroid bone loss is completely reversible, as shown by the follow up of patients treated for Cushing's syndrome ${ }^{9}$ and examination of 
patients whose treatment with steroids ceased some time earlier. ${ }^{10}$

The question of a "safe" dose-one that does not cause bone loss-is controversial. No long term prospective studies are available; most data are derived from cross sectional studies or short term follow up. Some authors have claimed that daily doses of $7.5 \mathrm{mg}$ or less of prednisone are relatively safe,,$^{11-14}$ but others have disagreed..$^{10-17}$ One interpretation of these data is that a subgroup of patients may be highly sensitive even to low doses. Probably for most patients the cumulative dose is more important-and so alternate day treatment does not seem to offer any advantages. ${ }^{18}$ Many former users have been shown to have normal bone density, so for most people treatment with low doses for between six and 12 months seems unlikely to lead to clinical sequelae.

Faced with a patient requiring longer term steroids at relatively low doses, such as $7-10 \mathrm{mg}$ daily of prednisone, the choice for the clinician is between reducing the dose and risking worsening of the disease (which may have a detrimental effect on inflammation and physical activity and so in turn adversely affect bone density) or continuing treatment and risking a possible subsequent fracture, the chances of which are unclear. At present there is no reliable way even of predicting which patients will lose bone while taking steroids, though if a lateral spine radiograph shows an existing vertebral fracture or the baseline bone density is low a poorer outcome seems likely. Biochemical markers of bone turnover, such as osteocalcin and urinary doxypyridinoline, alter dramatically in patients given steroids, ${ }^{19}$ but they are not sufficiently sensitive or specific to predict rapid losers of bone.

1 Cushing $\mathrm{H}$. The basophil adenomas of the pituitary body and their clinical manifestations (pituitary basophilism). Bull fohns Hopkins Hosp 1932;1:137-92.

2 Sambrook PN, Birmingham J, Kempler S, Kelly P, Eberl S, Pocock N et al. Corticosteroid effects on proximal femur bone loss. $¥$ Bone Miner Res 1990;5:1211-6.

3 Gennair C, Citivelli R. Glucocorticoid-induced osteoporosis. Clin Rheum Dis 1986;12:637-54.

4 Compston JE, Judd D, Crawley EO, Evans WD, Evans C, Church HA. Osteoporosis in patients with inflammatory bowel disease. Gut 1987;28:410-5.

5 Adinoff AD, Hollister JR. Steroid-induced fractures and bone loss in patients with asthma. $N$ Engl fMed 1983;309:265-8.

6 Spector TD, Hall GM, McCloskey EV, Kanis JA. Risk of vertebral fracture in women with theumatoid arthritis. BMF 1993;306:558.

7 Hooyman JR, Melton LJ, Nelson AM, O'Fallon MW, Riggs BL. Fractures after theumatoid arthritis: a population based study. Arthritis Rheum 1984;27:1353-61.

8 Luengo M, Picado C, Del Rio L, Guanabens N, Montserrat JM, Setoain J. Vertebral fractures in steroid dependent asthma and involutional osteoporosis: a comparative study. Thorax 1991;46: 9 Pocock NA, Eisman JA, Dunstan CR, Evans RA, Thomas DH, Huq NL. Recovery from steroid-
induced osteoporosis. Ann Interm Med 1987;107:319-23.

10 Hall GM, Spector TD, Griffin AJ, Jawad ASM, Hall ML, Doyle DV. The effect of rheumatoid arthritis and steroid therapy on bone density in postmenopausal women. Arthritis Rheum (in press).

11 Sambrook PN, Eisman JA, Champion GD, Pocock NA, Yeats MG, Eberl S. Osteoporosis in rheumatoid arthritis: safety of low dose corticosteroids. Ann Rheum Dis 1986;45:950-3.

12 Verstraeten A, Dequeker J. Vertebral and peripheral bone mineral content and fracture incidence in postmenopausal patients with theumatoid arthritis. Am Rheum Dis 1986;45:852-7.

13 Leboff MS, Wade JP, Mackowiak S, Fuleihan E, Zangari M, Liang MH. Low dose prednisolone does not affect calcium homeostasis or bone density in postmenopausal women with theumatoid arthritis. I Rheumatol 1991;18:339-44.

14 Reid IR, Heap SW. Determinants of vertebral mineral density in patients receiving long-term glucocorticoid therapy. Arch Intern Med 1990;150:2545-8.
If the steroids cannot be reduced or avoided what other options are available? All the studies to date are limited in that they are based on bone density as an outcome and not on fractures-though the two are likely to be related. A controlled study of the bisphosphonate drug pamidronate has shown a beneficial effect on spinal bone density in patients with asthma with established osteoporosis, ${ }^{20}$ and a recent large randomised study has shown that calcitrol $0.6 \mu \mathrm{g}$ daily prevents loss of bone from the spine in patients starting treatment with steroids at an average dose of $13.5 \mathrm{mg}$ a day. ${ }^{21}$ Several other agents show promise, ${ }^{22-26}$ but the best setting for these preparations is not yet known, nor whether they prevent fractures.

In clinical practice patients prescribed low doses of steroids for under 12 months can be reassured. Those starting long term treatment should be advised to have an adequate intake of calcium, to take oestrogen replacements if they are women past the menopause, and on the basis of published controlled studies consider preventive treatment with vitamin $D$ analogues or bisphosphonates to reduce vertebral bone loss. Uncertainty will be removed only by prospective studies with fractures as an end point.

T D SPECTOR

Department of Rheumatology,

Consultant rheumatologist

St Thomas's Hospital,

London SE1 7EH

P N SAMBROOK

Garvan Institute of Medical Research, Senior staff specialist

St Vincent's Hospital,

Sydney,

Australia

15 Laan RFJM, van Riel PLCM, van Erning LJT, Lemmens JAM, Ruijs SHJ, van de Putte LBA. Vertebral osteoporosis in theumatoid arthritis patients: effect of low dose prednisone therapy. $\mathrm{Br}$ f Rheumatol 1992;31:91-6.

16 Butler RC, Davie MWJ, Worsfold M, Sharp CA. Bone mineral content in patients with rheumatoid arthritis: relationship to low-dose steroid therapy. Br $\mathcal{F}$ Rheumatol 1991;30:86-90.

17 Reid DM, Nicoll J, Smith J, Higgins B, Tothill P, Nuki G. Corticosteroids and bone mass in asthma: comparisons with rheumatoid arthritis and polymyalgia. $B M^{\mathcal{F}} 1986 ; 293: 1463-6$.

18 Gluck OS, Murphy WA, Hahn TJ, Hahn BH. Bone loss in adults receiving alternate day glucocorticoid therapy: a comparison with daily therapy. Anthritis Rheum 1981;24:892-8.

19 Pertez A, Praet J-P, Bosson D, Rozenberg S, Bourdoux P. Serum osteocalcin in the assessment of corticosteroid induced osteoporosis effect of long and short term corticosteroid therapy. $f$ Rheumatol 1989;16:363-7.

20 Reid TR, King AR, Alexander CJ, Ibbertson HK. Prevention of steroid-induced osteoporosis with (3-amino-1-hydroxypropylidine)-1,1-bisphosphonate (APD). Lancet 1988;i:143-6.

21 Sambrook PN, Birmingham J, Kelly PJ, Kempler S, Pocock NA, Eisman JA. Prevention of corticosteroid osteoporosis; a comparison of calcium, calcitriol and calcitonin. N Engl f Med 1993;328:1747-52.

22 Lukert BP, Johnson BE, Robinson RG. Estrogen and progesterone replacement therapy reduces glucocorticoid-induced bone loss. F Bone Miner Res 1992;7:1063-9.

23 Grecu EO, Weinshelbaum A, Simmons R. Effective therapy of glucocorticoid-induced osteoporosis with medroxyprogesterone acetate. Calcif Tissue Int 1990;46:294-9.

24 Montemurro L, Schiraldi G, Fraidi P, Tosi G, Riboldi A, Rizzato G. Prevention of cortico steroid induced osteoporosis with salmon calcitonin in sarcoid patients. Calcif Tiss Int! 1991, 49:71-6.

25 Adami S, Fossaluzza V, Rossini M, Fertoldo F, Gatti D, Zamberlan N, et al. Prevention of corticosteroid-induced osteoporosis with nandrolene decanoate. Bone Mine 1991;15: 72-81.

26 Messina OD, Barriera JC, Zanchetta JR, Maldonado-Cocco JA, Bogado CE, Sebastian ON et al. Effect of low doses of Deflazacort vs prednisolone on bone mineral content in premenopausal rheumatoid arthritis. I Rheumatol 1992;19:1520-6. 